\title{
S11-6
}

\section{ヒト前立腺癌間質細胞による，前立腺癌細胞増殖効果における シグナル伝達経路についての解析}

帝京大学医学部泌尿器科学 ${ }^{11}$, 神戸大学医学部国際交流センター ${ }^{21}$, エモリー大学泌尿器科 ${ }^{3)}$

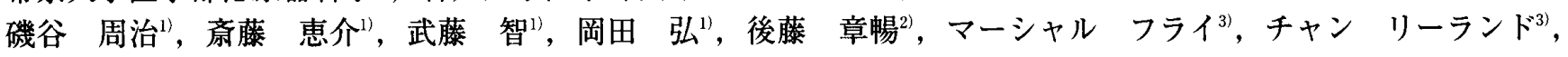
堀江 重郎 ${ }^{11}$

前立腺癌において、間質細胞の果たす役割は未知の部分が多いが、前立腺癌の悪性化に関与するとの報告も見られ る。今回我々はヒト前立腺間質細胞を初代培養することにより、前立腺癌における前立腺癌上皮一間質相互作用、 特にアンドロゲンレセプター (AR) と MAP キナーゼシグナル伝達経路のクロストークについての解析を行ったの で報告する。(方法) 根治的前立腺摘除術の組織よりヒト前立腺間質細胞を初代培養した。間質細胞の調整培養液を 用いて、前立腺癌細胞に対する細胞増殖作用、接着非依存性増殖、MAP キナーゼの活性化、及び ARのリン酸化に 関して検討を行い、前立腺癌細胞においての MAP キナーゼによるARのリン酸化について解析を行った。(結 果) ヒト前立腺間質細胞の調整培養液の添加により前立腺癌細胞の細胞增殖及び、接着非依存性増殖を認めた。前 立腺癌細胞内の MAP キナーゼは時間依存性に活性化されており、同時に ARのリン酸化も認められた。免疫沈降 法により精製された前立腺癌細胞の MAP キナーゼは in vitroにおいて ARをリン酸化し、シグナル伝達経路のク ロストークが示唆された。(まとめ) ヒト前立腺間質細胞による、ARを介した前立腺癌細胞增殖作用にシグナル伝 達経路のクロストークが存在すると考えられた。

\section{S11-7}

\section{尿路上皮癌のプロテオーム解析より同定した新規タンパク質に関する検討}

滋賀医科大学泌尿器科学 ${ }^{1}$, 滋賀医科大学附属実験実習センター ${ }^{2)}$, 滋賀医科大学微生物学講座 ${ }^{3)}$, 京都大学ウイルス研究所生体応答部門生体防御分野 ${ }^{4)}$, 京都大学(医学部輸血細胞治療部 ${ }^{5)}$ 影山 進 ${ }^{11}$, 吉貴 達寛 ${ }^{11}$, 岩城 秀出洙 ${ }^{11}$, 礒野 高敬 ${ }^{2}$, 井上 寛 ${ }^{32}$, 上田 正道 ${ }^{4)}$, 湯浅 健 ${ }^{5)}$, 岡田 裕作 ${ }^{1)}$

ある組織・細胞中に存在する夕ンパク質を網羅的に解析する『プロテオーム解析』という言葉は、すでに広く認知されつつ あり、これに関する論文も飛躍的に増加している。しかしながら、そこで得られた成果が臨床の場に還元された例は乏しく、 未だ発展途上の分野である。われわれは 2000 年よりプロテオーム解析による尿路上皮癌の新規尿中マーカー探索に取り組

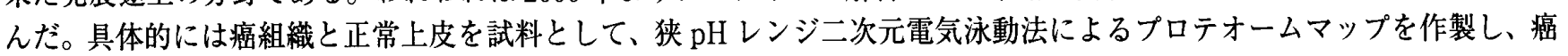
で up-regulation が見られるものをマーカー候補としてピックアップするという方法である。これまでのところ calreticulin などが尿路上皮癌患者尿から高頻度で検出され、尿中診断マーカーとして有用であると報告した (Kageyama et al., Clinical Chemistry 2004 ; Iwaki et al., Cancer Science 2004)。この実験過程で、ピックアップしたタンパク質の一つにゲノムデー タベース上の hypothetical protein である C7orf24 を同定することができた。この分子に既知のドメインは無く、機能未知の タンパク質である。マウスをはじめとして多くの生物にホモログがあるが、いずれも hypothetical protein として登録されて おり、機能推定がきわめて困難である。早速、大腸菌発現リコンビナントC7orf 24 タンパク質を作製しマウスに免疫したと ころ、幸いにも良質のモノクローナル抗体を樹立することが出来た。この抗体を用いて各種細胞株あるいは手術標本におけ る immunoblot を行うと、癌でC7orf24の高発現が認められ、プロテオーム解析の結果を裏付けるものであった。機能を明 らかにする目的で遺伝子導入実験を繰り返し、明らかな癌性変化は見出せないものの導入細胞に不死化の傾向が認められ た。また、機能抑制実験としてRNAi 法を行ったところ、C7orf24 タンパクの著しい発現低下が確認でき、細胞增殖能の抑 制が見られた。現在も検証実験を継続中である。プロテオーム解析がもたらしてくれた一連の知見を報告する予定である。 